\title{
RACIAL DISPARITY AND THE DEATH PENALTY
}

\author{
JOHNC.MCADAMS* \\ INTRODUCTION
}

We should, generally, want fairness in all areas of public policy. We should especially want fairness with regard to the death penalty, since the stakes are so high. $Y$ et the opponents of the death penalty make a most peculiar argument about fairness. They argue that if the death penalty is not administered fairly, and especially not administered with racial fairness, it must be abolished. ${ }^{1}$

Nobody would even think of trying to apply this principle in a consistent way. If we find that black neighborhoods get less police protection than white neighborhoods, would we withdraw cops from both black and white neighborhoods? If banks are discriminating against black home buyers in mortgage lending, would we demand they stop all mortgage lending? If we find the IRS discriminating against middle-class and poor taxpayers, would we want to abolish the IR S?

The first question, of course, is whether the death penalty is administered unfairly. A mong right-thinking, politically correct people, the phrase "racial unfairness" is a mere tautology. It is difficult to imagine that anything in A merican society is administered with racial fairness. But, in fact, the opponents of capital punishment have both a "mass market" version of the racial disparity argument and a "specialist" version, ${ }^{2}$ and the two versions are flatly contradictory. In what follows, I will first examine the rhetoric and data supporting the "mass market" version of the racial disparity thesis. I will then look at the best studies of racial disparity, which lead to a discussion of the (empirically superior) "specialist" version of the thesis. Next, I will present a new statistical analysis (based on previously published data) that attempts to

Copyright (c) 1998 by L aw and Contemporary Problems

This article is also available at http://www.law.duke.edu/journals/61L CPM cA dams.

* A ssociate Professor of Political Science, M arquette U niversity.

1. See, e.g., Callins v. Collins, 510 U.S. 1141, 1143 (1994) (Blackmun, J., dissenting from denial of certiorari to Callins v. Collins, 998 F.2d 269 (5th Cir. 1993)); Furman v. Georgia, 408 U.S. 238, 257 (1972) (B rennan, J., concurring); id. at 314 (M arshall, J., concurring); A merican Bar A ss'n, R esolution of the House of Delegates (Feb. 1997), reprinted in A ppendix, 61 LAW \& CONTEMP. PROBS. 219 (A utumn 1998); Leslie Harris, The ABA Calls for a M oratorium on the D eath Penalty: The Task A head-Reconciling J ustice with Politics, Fo CU S L. STU D., Spring 1997, at 2; Christine W iseman, Representing the Condemned: A Critique of Capital Punishment, 79 M A RQUETTE L. REV . 731 (1996). (1996).

2. See J ohn McA dams, Wisconsin Should A dopt the Death Penalty, 79 MARQUETTE L. REV. 719 
sort out various kinds of possible racial bias. Finally, I will consider the normative implications of the empirical findings.

II

\section{The "Mass Market" Racial Disparity A Rgument}

The "mass market" racial disparity argument is that the criminal justice system is tougher on black offenders than white offenders, and particularly is more inclined to execute blacks than whites. This argument is simple, palatable, and easy to sell. It flows effortlessly from our generic presumption that black people will be treated unfairly by pretty much any A merican institution, and from the ease of focusing on one particular class of black people: those accused of crimes. It is also supported by casual empiricism. A s Frank Chapman put this issue, "[f]or 48 percent of the death row population in our country to be [b]lack is clearly practicing genocide when you consider that A fro-A mericans are only 12 percent of the population." ${ }^{3}$ Presumably, this disparity is the result of racist prejudice on the part of prosecutors, juries, or the voting public to whom judges and prosecutors are responsible in a democracy. L eigh B ienen argues,

The criminal justice system is controlled and dominated by whites, although the recipients of punishment, including the death penalty, are disproportionately black. The death penalty is a symbol of state control and white control over blacks. Black males who present a threatening and defiant personae are the favorites of those administering the punishment, including the overwhelmingly middle-aged white, male prosecutors who-in running for election or reelection-find nothing gets them more votes than demonizing young black men. ${ }^{4}$

A s with any mass market commodity, this one is popular. For example, J esse J ackson, in a book titled $L$ egal $L$ ynching, claims

[n] umerous researchers have shown conclusively that A frican A merican defendants are far more likely to receive the death penalty than are white defendants charged with the same crime. For instance, A frican A mericans make up 25 percent of A labama's population, yet of A labama's 117 death row inmates, 43 percent are black. Indeed, 71 percent of the people executed there since the resumption of capital punishment have been black. ${ }^{5}$

It is also common to treat this issue in the historical context of the Slave Codes, which imposed particularly harsh punishments on blacks and lynchings. ${ }^{6}$

It is indeed the case that blacks are over-represented on death row. The Sourcebook of Criminal J ustice Statistics shows $41.7 \%$ of the death row population to be black, and $38.7 \%$ of all prisoners executed since 1977 have been $17,19$.

3. Frank Chapman, The D eath Penalty, USA : Racist and Class Violence, PoL. A FF., J uly 1987, at

4. The D eath Penalty: A Scholarly Forum, FocU S L. STU D., Spring 1997, at 1, 7 (remarks of Leigh Bienen).

5. Jesse jackson, Legal Lynching: Racism, injustice, and the Death Penalty 100 (1996). H owever, J ackson also admits that "the relationship between race and capital punishment is much more complex than most people suppose." Id.

6. See, e.g., Raymond Paternoster, Ca pital Punishment in A merica 116-19 (1991). 
black. ${ }^{7}$ B ut then suppose we look a bit further. We come face to face with the reality shown in Table 1.

TABLE 1

Murders and Nonnegligent ManSLA UGHTERS KNOWN TO POLICE UNITED STATES, 1995

\begin{tabular}{cccc}
\hline & \multicolumn{2}{c}{ R ace of O ffender } & \\
R ace of V ictim & W hite & B lack & Total \\
\hline W hite & 4,124 & 699 & 4,823 \\
B lack & 281 & 4,422 & 4,703 \\
\hline Total & 4,405 & 5,121 & \\
\hline
\end{tabular}

SOURCE: SOURCEBOOK OF CRIMINAL JUStice Statistics (1996). O mitted are cases where either the victim or the offender was of the "other" racial classification, or was unknown.

The data in Table 1 shows that forty-eight percent of murder victims are black. It also shows that the vast majority of murders are intraracial not interracial. A mong murders involving black and white persons, ninety percent involve a white killing a white or a black killing a black. A Imost three-quarters of the rest involve blacks murdering whites, and only a small handful involve whites murdering blacks. K nowing this, the number of blacks on death row and the number of blacks executed do not look far out of line.

To get a solid assessment of bias, however, we need to go beyond eyeballing numbers. We have to control for factors that might legitimately result in more or fewer severe sentences. In arguing that racial bias exists in the system, the opponents of the death penalty have actually cited the fact that blacks who murder whites are treated more harshly than blacks who murder blacks. U nfortunately, the probability of black-on-white murders being comparable to black-on-black murders are about zero.

So the key is to compare how black murderers are treated relative to white murderers who commit comparable murders. Likewise, we must analyze what sort of punishment is meted out to those who murder blacks as compared to those who murder whites under similar circumstances. In the following section, I will review the literature on race and the death penalty, with particular attention to studies that control for the factors that might legitimately result in a more severe sentence-such as the murder being connected with the commission of a felony, the presence of multiple victims, and a prior conviction for a capital felony.

7. See Sourcebook of Criminal Justice Statistics 556 (1996); see also U.S. Dep't of Justice, Bureau of Justice Statistics Bulletin-Capital PUNISHMent 1995, at 11 (1996) (listing statistics on executions and persons under sentence of death in 1995). 
III

\section{A SSESSING RA CIAL UNFAIRNESS}

In attempting to assess whether racial bias exists in the application of the death penalty, there are about as many methodological problems as in any other policy area of social science research. First, there is the question of what historical era we are studying. The watershed is the Furman v. Georgia ${ }^{8}$ decision, in which the Supreme Court required that the application of the death penalty meet certain standards of supposed procedural fairness. This decision might not have been a watershed, however, because it is possible that the sources of unfairness in the system were simply not capable of being remedied by the reforms put into place after Furman. Indeed, it is quite possible that such reforms made the system less fair. ${ }^{9}$ If so, this would not be the first time that reform produced unintended consequences. ${ }^{10}$ Be this as it may, postFurman data must be presumed to be a better indicator of the way the system operates today.

A nother methodological problem with assessing racial bias in the death penalty system concerns state-to-state and rural-versus-urban differences. A n analysis that is disaggregated along these lines may very well show important variation across jurisdictions. Such variation may shed light on important dynamics. For example, D avid B aldus and his colleagues found that rural and urban areas in G eorgia had radically different patterns of racial disparity. ${ }^{11} \mathrm{H}$ owever, the more one disaggregates the data, the smaller the number of cases in the relevant categories, and the less our chance of establishing facts with any level of statistical confidence. We may quickly find ourselves trying to make sense of variations across jurisdictions that are mere statistical phantoms.

Finally, there is the question of identifying our dependent variable. Because we are talking about the death penalty, it seems sensible to study who has been executed. U nfortunately, it is not so simple. Executions are so few as to make statistical inferences difficult. I ronically, the same reality that makes it difficult to show that capital punishment deters murders also makes it difficult to show racial disparity. ${ }^{12}$ So it is common in the research to look at death sen-

8. 408 U .S. 238 (1972).

9. One reform that looks particularly suspect is the use of a bifurcated trial, with the jury deciding the sentence in what amounts to a second trial. These proceedings often degenerate into blatant attempts to manipulate the emotions of the jury.

10. For example, the imposition of tough mandatory sentences for certain offenses has caused offenders to demand trials rather than plea-bargain (N ew Y ork's "R ockefeller drug laws"), nearly doubling the time necessary to dispose of an average case. In M ichigan, a tough bill imposing a mandatory sentence for possessing a firearm while committing a felony led to judges reducing the original sentence for the original felony to compensate for the mandatory firearm possession sentence. See JAMES Q. WILSON, THINKING A BOU T CRIME 133-36 (rev. ed., V intage Books 1985) (1975).

11. See infra note 32 and accompanying text.

12. A rnold Barnett, for example, reviewed Passell's 1975 study which had found no deterrent effect. See A rnold Barnett, The D eterrent Effect of Capital Punishment: A T est of Some Recent Studies, 29 O PERA TIONSRES. 346, 353 (1981). B arnett found that the model estimated by Passell had a prediction error-in terms of the number of homicides- of 1,635. See id. at 354 . B ut there were only 44 persons executed for murder in 1960. See SOURCEBO OK OF CRIM INA L J U STICE STA TISTICS 462 (1973). If 
tences (regardless of whether they were carried out) or the prosecutors' decision to ask for the death penalty (regardless of whether it is received). This methodology achieves plausible results, but they are hardly ironclad. For example, if blacks are more likely to be sentenced to death, but are also more likely to attract post-sentencing counsel from among the ranks of political activist anti-capital punishment lawyers, a racial disparity in sentencing might be counterbalanced by an opposite disparity in the appeals process.

O ne important study that spanned the pre- and post-F urman eras was conducted by Gary K leck. ${ }^{13}$ Kleck looked at the imposition of death sentences from 1967 to 1978 and at actual executions during 1930 to 1967 . He found that, outside the South, black homicide offenders have been less likely than white offenders to be sentenced to death or executed. In the South, a pattern of apparent discrimination against black offenders in the early data disappeared in more recent data. B etween 1950 and 1967, black offenders and white offenders seemed to be executed at identical rates in the South. ${ }^{14}$ Lawrence $\mathrm{G}$ reenfeld and David H inners used a mode of analysis similar to Kleck's, but with more recent data. They reported that for each thousand blacks arrested for murder or nonnegligent manslaughter, 11.6 were sentenced to death. ${ }^{15}$ A mong whites, the rate was 15.8 per thousand. ${ }^{16}$ The relatively lenient treatment of black homicide offenders is striking, but neither of these studies controlled for the race of the victim, which is a critical factor.

M ost of the best studies have been state-specific. Sheldon Ekland-O Ison, for example, examined data from cases in Texas brought between 1974 and 1983. ${ }^{17}$ The choice of Texas was significant, since the death penalty statute in Texas allowed less discretion than statutes in other states, such as Florida and G eorgia. ${ }^{18}$

E kland-O Ison showed, first, that the death row population overrepresented offenders who killed strangers and underrepresented offenders who killed acquaintances-a fact that makes clear the uselessness of comparing interracial murders with intraracial murders, ${ }^{19}$ and, second, that offenders who killed whites were overrepresented, and those who killed blacks or $\mathrm{H}$ ispanics were underrepresented on death row. ${ }^{20}$ Ekland-OIson also showed-as we would

each of these executions had deterred five murders, which would be an excellent "return" in terms of deterrence, the reduction of 220 murders would not have been discernible in Passell's data within accepted standards of statistical reliability. See id. at 355.

13. See Gary Kleck, Racial Discrimination in Criminal Sentencing: A Critical Evaluation of the Evidence with A dditonal Evidence on the D eath P enalty, 46 A M. So C. R E V. 783 (1981).

14. Seeid. at 798-99.

15. See Lawrence G reenfeld \& D avid Hinners, Capital Punishment 1984, U S. DEP'T OF J USTICE, BuREA U OF JUSTICE StA TISTICS BULLETIN 1, 9 (1985).

16. Seeid.

17. See Sheldon E kland-O Ison, Structured $D$ iscretion, $R$ acial B ias, and the $D$ eath $P$ enalty: The First Decade A fter Furman in Texas, 69 So C. SCl. Q . 853, 854 (1988). It is important to note that EklandO Ison studied death sentences rather than actual executions.

18. Seeid.

19. See id. at 861 .

20. Seeid. 
expect because the vast majority of murders are intraracial-that whites were overrepresented on death row. ${ }^{21}$

R aymond Paternoster, using data from South Carolina on the probability that prosecutors will seek the death penalty in homicide cases, likewise found, even after the imposition of a fairly complete set of control variables, that cases where whites killed whites were much more likely to result in a death penalty request than cases of a black killing a black. ${ }^{22}$ Interestingly, Paternoster looked for effects of the race of the accused, but failed to find any that showed statistical significance. $^{23}$

Using data from Florida, William J. Bowers found that blacks who killed whites, and whites who killed whites were substantially more likely to be indicted for and convicted of first-degree murder than blacks who killed blacks. ${ }^{24}$ The data showed that blacks who killed whites and whites who killed whites were more likely to be sentenced to death, but B owers could not establish this with the degree of statistical confidence that applied to the other two findings. ${ }^{25}$ This study is interesting because the evidence of racial disparity in indictment and conviction is better than the evidence of disparity in sentencing. $Y$ et it is only the latter that is addressed by the abolition of the death penalty.

$M$ ichael R adelet in his study also used Florida data, looking at 637 homicide indictments. He looked for race-of-victim and race-of-defendant effects on both indictment for first-degree murder (as opposed to a lesser charge) and the imposition of a death sentence. He used a single variable to control for the heinousness of the crime: whether the defendant and the victim knew each other. He made no serious attempt to look for racial disparity in "primary" murder cases (in which the victim and defendant were acquainted) since the death penalty was so rarely imposed in such cases. A mong the other cases, in spite of an unfortunately convoluted statistical analysis, he found robust raceof-victim effects for both indictments and sentences. ${ }^{26}$ However, a study by Linda Foley and R ichard Powell that included many of the same cases and had a more complete set of statistical controls for the severity of the case showed no statistically significant race-of-victim effects for prosecutors' decisions to seek the death penalty nor on juries' decisions to levy a death penalty. ${ }^{27}$ They did show such effects for sentences imposed by trial judges, however. ${ }^{28}$

\footnotetext{
21. Seeid.

22. See Raymond Paternoster, Race of Victim and L ocation of Crime: The D ecision to Seek the Death Penalty in South Carolina, 74 J. CRIM . L. \& CRIMINOLOGY 754, 767 (1983).

23. See id. at 766.

24. See William J. Bowers, The Pervasiveness of A rbitrariness and Discrimination Under PostFurman Capital Statutes, 74 J. CRIM. L. \& CRIM IN OLOGY 1067, 1074 (1983).

25. Seeid. at 1085.

26. See M ichael L. R adelet, Racial Characteristics and the Imposition of the D eath P enalty, $46 \mathrm{~A} M$. Soc. REV. 918-27 (1981).

27. See Linda A . Foley $\&$ R ichard S. Powell, The D iscretion of Prosecutors, J udges, and J uries in Capital Cases, 7 CRIM . J UST. REV. 16 (1982).

28. Seeid. at 21.
} 
G ennaro V ito and Thomas K eil studied all persons indicted for murder in Kentucky between D ecember 22, 1976, and 0 ctober $1,1986 .{ }^{29}$ They looked for racial disparity in the decision of a prosecutor to ask for a death-qualified jury. ${ }^{30}$ They found that offenders who had murdered whites were more likely to face a death-qualified jury than offenders who had murdered blacks. ${ }^{31}$

Perhaps the most elaborate study was conducted with data from $\mathrm{G}$ eorgia by $D$ avid $B$ aldus and his colleagues. ${ }^{32}$ A key element in this study was the prosecutors' decision to seek the death penalty. A fter extensive controls, clear raceof-victim effects emerged-although at the middle levels of aggravation. Specifically, where there were three or four statutory aggravating factors, prosecutors were far more likely to seek the death penalty when the victims were white. $^{33}$

$\mathrm{N}$ ot all important death penalty studies come from southern states. For example, Leigh Bienen and her colleagues examined homicides in $\mathrm{N}$ ew J ersey committed during 1982 to 1986, 703 in all. ${ }^{34}$ A s with several other studies, the dependent variable was not execution, nor even a death sentence, but rather a prosecutor's decision to seek the death penalty. ${ }^{35}$ The study found that a higher percentage of white defendants were charged with capital murder. ${ }^{36}$ H owever, this was apparently because white defendants usually had killed white victims, since the victim's race had strong effects on the charge. ${ }^{37}$ Forty-three percent of defendants who had killed a white were charged with capital murder, as opposed to twenty-eight percent who had killed a black, and nineteen percent who had killed an H ispanic. ${ }^{38}$ These racial disparities held up in the presence of elaborate statistical controls. ${ }^{39}$

29. See Gennaro F. Vito \& Thomas J. Keil, Capital Sentencing in Kentucky: An A nalysis of the Factors Influencing Decision Making in the Post-Gregg Period, 79 J. CRIM. L. \& CRIMINOLOGY 483 (1988).

30. A "death qualified jury" is one in which each juror has been told that the death penalty is possible in the case and that has not demonstrated that it is entirely unwilling to impose a death sentence. See Vito \& Keil, supra note 29, at 493; see also WELSH S. WhITE, THE DEATH PenALtY IN the EIGHTIES Ch. 8 (1987).

31. See V ito \& K eil, supra note 29 , at $498-99$.

32. See $D$ avid $C$. Baldus et al., Comparative Review of D eath Sentences: A $n$ E mpirical Study of the Georgia Experience, 75 J. CRIM. L. \& CRIMINOLOGY 661 (1983) [hereinafter Baldus, Comparative Review]; see also DA VID C. BA LDUSET AL., EQUAL J USTICE AND THE DEATH PENALTY (1990).

33. See B aldus, Comparative R eview, supra note 32, at 709.

34. See Leigh Bienen et al., The Reimposition of Capital Punishment in N ew Jersey: The Role of Prosecutorial D iscretion, 41 R UTGERS L. REV . 27, 37 (1988).

35. Seeid. at 165.

36. Seeid. at 170.

37. See id. at 192.

38. Seeid. at 172.

39. See id. at 226, 235. 
IV

\section{The "SPECIA LIST" Ra CIA L DISPARITY A RGUMENT}

The "specialist" version of the racial disparity argument is that the criminal justice system discriminates against blacks by its lack of concern for black victims. A s A nthony A msterdam has claimed, "although less than 40 percent of Georgia homicide cases involve white victims, in 87 percent of the cases in which a death sentence is imposed, the victim is white. White-victim cases are almost eleven times more likely to produce a death sentence than are blackvictim cases." $^{40} \mathrm{R}$ andall L. K ennedy, describing the same Baldus study, lamented what he described as the fact that "in Georgia's marketplace of emotion the lives of blacks simply count for less that the lives of whites." ${ }^{41}$

In a considerable display of chutzpah, the opponents of capital punishment, who first adopted an offender-centered concept of justice (when it was convenient to argue that too many blacks were being executed), simply turned on a dime and adopted a victim-centered concept of justice (when the data in fact showed that too many whites are being executed). Had they maintained philosophical consistency, the opponents might have lauded the current situation on the ground that a sort of affirmative action was being employed. That is, against an historic background of harsh treatment of black people in most aspects of public policy, black offenders are getting favorable treatment from the criminal justice system. Instead, the opponents decided that victims matter after all.

E ven worse is the opponents' tendency to adopt vague rhetoric about the evil of racism in an attempt to cover up the fact that they have turned on a dime. It is also troubling to find articles from authors who clearly have data that might show discrimination based on the race of the offender, but who do not present it and choose instead to discuss the race of the victim. For example, Sam G ross and R obert M auro present a table containing the following data: ${ }^{42}$

40. A nthony G. A msterdam, Race and the D eath Penalty, 7 CR IM . J U STICE E THICS 2, 84 (1988).

41. R andall L. Kennedy, M cCleskey v. Kemp: Race, Capital Punishment, and the Supreme Court, 101 HAR V. L. REV . 1388 (1988).

42. See Samuel R. GRoss \& Robert Mauro, Death \& Discrimination: Racial DisPARITIESIN CAPITAL SENTENCING 47 (1989). 
TABLE 2

Percentage of Death Sentencesby Ra Ce of Suspect AND VICTIM, AND FELONY CIRCUMSTANCES, FLORIDA

\begin{tabular}{lcc}
\hline & $\begin{array}{c}\text { Felony } \\
\text { Circumstances }\end{array}$ & $\begin{array}{c}\text { Nonfelony } \\
\text { Circumstances }\end{array}$ \\
\hline B lack kills white & $28.8 \%$ & $2.5 \%$ \\
& $32 / 111$ & $2 / 79$ \\
W hite kills white & $26.9 \%$ & $1.4 \%$ \\
& $63 / 234$ & $17 / 1187$ \\
B lack kills black & $6.0 \%$ & $0.3 \%$ \\
W hite kills black & $7 / 116$ & $4 / 1414$ \\
& $18.2 \%$ & $1.9 \%$ \\
W hite victim & $2 / 11$ & $1 / 53$ \\
& $27.5 \%$ & $1.5 \%$ \\
Black victim & $95 / 346$ & $19 / 1272$ \\
& $7.0 \%$ & $0.3 \%$ \\
\hline
\end{tabular}

NOTE: A mong the states analyzed in the body of the book, I have chosen to report their data on Florida because it had the largest absolute number of death sentences. 0 ther states showed a similar pattern.

Q uite clearly, murders with a white victim were more likely to lead to a death sentence than murders with a black victim.

But what do Gross and Mauro not show the reader? I have derived the following table from their data:

TABLE 3

Percentage of Death Sentencesby Race of Suspect AND FELONY CIRCUMSTANCES, FLORIDA

\begin{tabular}{lcc}
\hline & Felony Circumstances & N onfelony Circumstances \\
\hline W hite Suspect & $26.5 \%$ & $1.4 \%$ \\
& $65 / 245$ & $18 / 1240$ \\
Black Suspect & $17.2 \%$ & $0.4 \%$ \\
& $39 / 227$ & $6 / 1493$ \\
\hline
\end{tabular}

The data are striking. White suspects are treated more harshly than black suspects, and this is especially true under nonfelony circumstances. So just what is going on here? Given the studies we have reviewed showing that the system is lenient on those who kill blacks, and knowing that the vast majority of murders are intraracial, we might conclude that white suspects get tougher treatment because they have overwhelmingly killed whites. This conclusion 
would be correct, but then we must ask whether the race of the suspect has any effect after we have controlled for the race of the victim.

\section{$\mathrm{V}$}

\section{RACE-OF-SUSPECT EFFECTS}

The published literature shows some race-of-suspect effects after controlling for the race of the victim, but they are few and lack statistical robustness. A mong the studies we discussed above, B owers reported no race-of-defendant effects. $^{43}$ R adelet looked for race-of-defendant effects, and found none neither for first-degree murder indictments, nor for death sentences. ${ }^{44}$ Likewise, Foley and Powell found none for prosecutors' decisions to seek the death penalty, nor for juries' decisions to levy the death penalty, nor for the actual sentences imposed by trial judges. ${ }^{45}$ Paternoster, as we have already noted, found no significant race-of-suspect effects. ${ }^{46}$

Bienen and her colleagues found no race-of-defendant effects with regard to the prosecutors' decision to plea bargain rather than go to trial. The pattern of effects for the prosecutors' decisions to "serve a notice of factors" (claim aggravating factors) is complicated, but there seems to be no net race-ofdefendant effect. ${ }^{47}$ Gross and $M$ auro claim to have found statistically significant race-of-suspect effects in Illinois. ${ }^{48}$ U nfortunately, they had no prior expectation that such effects would occur in Illinois (but not in the other seven states in their sample). So this looks like yet another example of the fact that, if you estimate a large number of coefficients, some will turn up "significant."

Given the appeal of the "mass market" version of racial unfairness in the system, many people will have difficulty accepting that there is no bias against black defendants.

In an attempt to answer this difficulty, we can use G ross and M auro's data and construct a statistical model of death sentences. The unit of analysis in the $G$ ross and $M$ auro data is homicides, and the dependent variable is a dichotomy based on whether a particular homicide resulted in a death penalty. N ote that this variable aggregates over a whole series of decision points: Is the suspect charged? Is he charged with first-degree murder? D oes the prosecutor ask for the death penalty? Does the jury convict and levy a death sentence? This approach has the virtue of producing a "bottom line" assessment of bias in the process, with the proviso that actual executions are not addressed. Gross and $M$ auro present data from eight states with a relatively large number of homicides, ${ }^{49}$ and include all homicides reported to the FBI from 1976 to 1980 . The

\footnotetext{
43. See B owers, supra note 24 , at 1073, 1079, 1084.

44. See $R$ adelet, supra note 26 , at $923-24$.

45. See Foley \& Powell, supra note 27 , at 21 .

46. See Paternoster, supra note 22 , at 770 .

47. See B ienen et al., supra note 34, at 226, 235.

48. See GROSS \& MAURO, supra note 42 , at 68-69.

49. A rkansas, Florida, G eorgia, Illinois, M ississippi, North Carolina, O klahoma, and V irginia.
} 
independent variables used here include both the race of the victim and the suspect, and a key control variable, the number of aggravating circumstances associated with the crime. A ggravating circumstances can include whether (1) the murder was associated with another felony, (2) the victim was a stranger, and (3) there was more than one victim. Gross and M auro found this control variable to be a powerful predictor of the likelihood of the imposition of a death sentence.

TABLE 4

Death Sentencesin HOMiCide Ca SES

LOGISTIC REGRESSION

(standard errors in parentheses)

\begin{tabular}{|c|c|c|c|c|}
\hline \multirow[b]{2}{*}{$\begin{array}{c}\text { Independent } \\
\text { V ariable }\end{array}$} & \multicolumn{4}{|c|}{ Equation } \\
\hline & 1 & 2 & 3 & 4 \\
\hline $\begin{array}{l}\text { A ggravating Cir- } \\
\text { cumstances }\end{array}$ & $\begin{array}{r}1.75 \\
(.065)\end{array}$ & $\begin{array}{r}1.60 \\
(.066)\end{array}$ & $\begin{array}{r}1.59 \\
(.068)\end{array}$ & $\begin{array}{r}1.58 \\
(.069)\end{array}$ \\
\hline Black Suspect & $\begin{array}{r}-.714 \\
(.113)\end{array}$ & & $\begin{array}{r}.066 \\
(.134)\end{array}$ & \\
\hline Black V ictim & & $\begin{array}{r}-1.56 \\
(.154)\end{array}$ & $\begin{array}{r}-1.60 \\
(.176)\end{array}$ & $\begin{array}{l}-1.61 \\
(.169)\end{array}$ \\
\hline $\begin{array}{l}\text { Black on White } \\
\text { M urder }\end{array}$ & & & & $\begin{array}{r}.144 \\
(.136)\end{array}$ \\
\hline $\begin{array}{l}\text { White on Black } \\
\text { Murder }\end{array}$ & & & & $\begin{array}{r}.937 \\
(.419)\end{array}$ \\
\hline Constant & -4.80 & -4.54 & -4.54 & -4.55 \\
\hline-2 log Likelihood & 3469.8 & 3469.9 & 3469.9 & 3469.8 \\
\hline
\end{tabular}

The first equation models death sentences as a function of aggravating circumstances and the race of the suspect. It shows a powerful and statistically robust effect of the number of aggravating circumstances. It also shows that, after the aggravation factor is taken into account, black defendants are treated more leniently than are white defendants. This is the same reality shown in Table 3 above. The second equation models death sentences as a function of aggravating circumstances and the race of the victim. A gain, aggravating circumstances show a large and robust effect, and now the race of the victim shows a large effect. A white victim has an effect almost precisely equal to the effect of one aggravating circumstance.

Suppose we take both the race of the victim and the suspect into account? These two variables are so highly correlated that we would suspect that coline- 
arity between them would give us mush for estimates. Y et, in fact, the third equation in the table is a pleasant surprise. O ur standard errors have increased only moderately. O ur estimates show that the race of the victim and not the race of the suspect matters. O ur standard error for the race of the suspect is small enough that any large effect would be statistically significant. A gain, murdering a white has an effect almost identical to one additional aggravating circumstance. That is, killing one white person is treated about the same as killing multiple black people, and killing a white nonstranger is treated about the same as killing a black stranger.

A final question remains about this data: Is there an interaction between the race of the victim and the race of the suspect? G iven that people who murder whites are treated more harshly than people who murder blacks, are blacks who murder whites treated more harshly than whites who murder whites? A nd is there a racial disparity in the treatment of people who murder blacks?

E quation 4 deals with these issues. The interaction of race-of-victim and race-of-suspect are modeled with a series of dummy variables. White-on-white murders are the excluded reference category. B lack-on-white murders seem to be treated no differently than white-on-white murders. In other words, net of aggravating circumstances, blacks and whites are treated about equally if they kill a white. A s expected, people who murder blacks are treated much less harshly than people who murder whites. H owever, our white-on-black variable estimates the difference between the treatment received by blacks who murder blacks and whites who murder blacks. It seems that whites who murder blacks are treated more harshly than blacks who murder blacks. D oes this suggest an anti-white racial bias in the system? Maybe and maybe not. It could be that most such murders happen in urban areas, and that biases of blacks on juries are the key factor. Or it might be that white-on-black murders are different in some way that our scale of aggravating circumstances does not pick up. Finally, white-on-black murders may be viewed as "hate crimes" and therefore particularly dangerous to society.

Some idea of the magnitude of these effects can be found in Table 5 . There the estimates from Table 4 are used to generate probabilities that homicides that fall into various categories will result in a death sentence. A s we might expect from the estimates, a black-on-black murder with no aggravating factors is extremely unlikely to result in a death sentence. A bout two per thousand of such murders produce this result. On the other hand, while a white who murders a white is about five times as likely to get the death penalty, it is still unlikely. A mong both blacks and whites, aggravating factors radically increase the probability of a death sentence, but all three aggravating factors are required to work against a defendant (an exceedingly unlikely event) in order to increase the probability of a death sentence in a black-on-black murder to the level of a white-on-white murder with only two aggravating factors. If only two aggravating factors are present in a black-on-black murder, the probability of a death sentence is only about five percent. 
TABLE 5

PROBABILITY THATA HOMICIDE WILL RESULTIN

a DeAth Sentence

\begin{tabular}{cccc}
\hline $\begin{array}{c}\text { R ace of } \\
\text { V ictim }\end{array}$ & $\begin{array}{c}\text { R ace of } \\
\text { Suspect }\end{array}$ & $\begin{array}{c}\text { Number of } \\
\text { A ggravating } \\
\text { Factors }\end{array}$ & $\begin{array}{c}\text { Probability } \\
\text { of a D eath } \\
\text { Sentence }\end{array}$ \\
\hline B lack & B lack & 0 & .0021 \\
B lack & B lack & 1 & .0102 \\
B lack & B lack & 2 & .0476 \\
B lack & B lack & 3 & .1955 \\
B lack & W hite & 0 & .0054 \\
White & W hite & 0 & .0105 \\
White & W hite & 2 & .1996 \\
\hline
\end{tabular}

This rather simplistic model is hardly the last word on this issue, but it does have very real virtues. It includes data on over 14,000 murders, separates raceof-victim and race-of-suspect effects, and uses a robust measure of the severity of the crime for a control.

Thus, the "specialist" version of the racial disparity argument appears to be correct. The data strongly suggest that the criminal justice system undervalues the lives of black victims. The findings presented here are consistent with those of $B$ aldus and his colleagues who used extensive controls for the nature of the murder and the number of aggravating factors present, and still found murderers of white victims to be more likely to be sentenced to death. ${ }^{50}$ Baldus is the preeminent scholar in this area, and he recently described the current state of the literature as follows:

[W] hat do the data tell us about differences in discrimination in the pre- and postFurman periods? There are significant differences in race effects, both across and within states. There are differences in the magnitude of race effects at different decision making levels in the states-i.e., prosecutorial decisions to seek the death penalty and jury decisions to impose death. There are also differences that correlate with culpability. The risk of race effects was very low in the most aggravated capital cases; however, in the mid-range cases, where the "correct" sentence was less clear; and the room for exercise of discretion much broader, the race disparities are much stronger. Whereas the overall average disparity for the two groups (Black $\mathrm{v}$. White) tends to be six to eight percentage points, in the mid-range cases the disparities are typically two to three times that large [twelve to twenty-four percentage points]. ${ }^{51}$

$B$ aldus then goes on to describe some reactions to his findings:

There is much anecdotal evidence from lawyers who represent capital defendants. $M$ any of them seriously question the validity of statistical studies that do not reveal disparities based upon the race of the defendant. It is possible that there is such dis-

50. See $B$ aldus, Comparative R eview, supra note 32 , at 708-10.

51. The D eath Penalty, supra note 4 , at 7 (remarks of D avid B aldus). 
crimination, but that it is not sufficiently large and systematic to be picked up by the data. ${ }^{52}$

Baldus, perhaps out of politeness, does not note that lawyers are in the business of producing "anecdotal evidence" to support their clients' position, and that those who represent capital defendants are a highly self-selected and hardly unbiased group.

I believe that, based on the analysis above, stronger statements than those of $B$ aldus are warranted. There is a general and quite robust bias against black victims, and there is no general bias against black defendants. ${ }^{53}$

\section{VI}

\section{THE CONSE QUENCES OF R A CISM}

So is the system racist? $Y$ es, but we need to be extremely careful, because nothing is more dangerous in politically correct sectors of society than loose talk about racism. Such talk is a balm, spreading a warm glow of selfrighteousness over those who use it. And it is an opiate, stifling critical thought. It is striking that the most straightforward hypothesis about racismthe "mass market" version-simply is not true. Why a bias against black victims-and potential victims- and not black offenders? It is the latter, after all, who are caught in the maw of the system.

Scholars and activists have devoted a huge amount of attention to the notion that juries may be racist, and therefore particularly harsh toward black defendants. ${ }^{54}$ A re we now going to posit that, lacking empathy for black victims, they are less willing to punish black defendants? This seems implausible. The jury has no direct control over the fate of any victim. I magine a jury consisting of members of the Ku K lux K lan. They doubtless have little empathy for the black victim, but presumably even less for a black murderer. So why treat a black offender, who is within their power, leniently? Of course, one could posit racist jurors who are malevolent, extremely shrewd and insightful, and understand that in the long run more damage can be done to the black community by letting black criminals off easy. I think this is insufficiently plausible to merit further discussion.

However, the notion that prosecutors and judges are less willing to expend the scarce resources of the criminal justice system to convict and execute the murderers of blacks is all too plausible. In fact, it is clearly the case. A Ithough this situation certainly needs to be remedied, it is not clear how abolishing the death penalty is any part of the remedy. M erely doing away with the death penalty does not guarantee that everybody will be treated fairly in murder cases. It merely guarantees that they cannot be executed.

52. Id. at 8 .

53. Saying "no general bias" does not deny that there might be bias in some places, under some circumstances.

54. See, e.g., Gregory D. Russell, The Death Penalty and Ra Cial Bias ch. 5 (1994). 
While we seek to remedy inequities in the A merican criminal justice system, we would do well to remember the words of $\mathrm{E}$ rnest van den $\mathrm{H}$ aag:

Guilt is individual. If guilty whites or wealthy people escape the gallows and guilty poor people do not, the poor or black do not become less guilty because the others escaped their deserved punishment. Whether due to willful discrimination, capriciousness, or unavoidable accidental circumstances, some people will always get away with murder. Is that a reason to deny the justice of the punishment of those guilty persons who did not get away? Their guilt is not diminished by the escape of the others, nor do they deserve less punishment because others did not get the punishment they deserve. Justice involves punishment according to what is deserved by the crime and the guilt of the criminal-regardless of whether others guilty of the same crime escape. ${ }^{55}$

The opponents of capital punishment are pushing an argument they would never use in other contexts. The fact that you parked illegally and did not get a ticket does not relieve me of paying the fine when I do get a parking ticket. The fact that you bamboozled the IRS does not make it acceptable for me to cheat on my taxes, and it certainly does not require the abolition of the IR S.

VII

\section{CONCLUSION}

Given that there is a real racial disparity here, how do we remedy it? Note that if one is already against the death penalty, the obvious remedy is abolition. On the other hand, applying the death penalty fairly is just as much a remedy. Interestingly, polls show a clear majority of black people favoring capital punishment. O ne Gallup Poll, for example, found that fifty-nine percent of blacks nationwide favored the death penalty, and that only thirty-one percent opposed it. $^{56}$ In another study, Linda Lichter commissioned a nationwide poll of blacks that contained 600 respondents, more than in any poll that fails to oversample blacks. A mong those respondents with an opinion, fifty-five percent favored the death penalty and forty-five percent opposed it. ${ }^{57}$ E ven sixty percent of the upscale readers of E bony said capital punishment is "the only just punishment" for murder. ${ }^{58}$

Now of course, a majority of black A mericans can just as easily be in the wrong as a majority of white A mericans. These data do show, however, the hollowness of the claim of the anti-death penalty forces to speak for black A mericans.

In saying that we should seek to eliminate inequity in the application of the death penalty, I am not asserting that such a thing will be easy, or even possible 193.

55. Ernest van den Haag, M urderers D eserve the Death Penalty, W ORLD \& I, N ov. 1989, at 189,

56. See A lec Gallup \& Frank Newport, Death Penalty Support Remains Strong, GALLUP POLL MONTHLY, J une 1991, at 40, 43. This was true even though $73 \%$ of black respondents agreed that "[a] black person is more likely than a white person to receive the death penalty for the same crime." Id. at 45. This shows the popular appeal of the "mass market" view of racial disparity discussed above.

57. See L inda S. Lichter, Who Speaks for B lack A merica?, PU B. O P., A ug.-Sept. 1985, at 41, 43.

58. E bony's A nnual Readers Poll, E BONY, N ov. 1994, at 43. This poll was far from scientific, but it is interesting both for the large number of respondents $(9,657)$ and for their relatively affluent nature. 
in the short or intermediate term. That inequity in the application of the death penalty requires its abolition is an argument that will be made only by people who do not like it for other reasons. The inequity argument is a pretext, not a reason. Between an inequitable death penalty and no death penalty, I would prefer an inequitable death penalty, just as I would prefer an inequitable tax system to no tax system, and inequitable policing to no policing. I say this because I think it likely that executions deter murders, ${ }^{59}$ and it is clear that a majority of A mericans-white and black - think that justice requires executions for the most heinous crimes. If someone says that capital punishment does not deter murder and that justice does not require it for the most heinous crimes, my response is that those are the real reasons they oppose the death penaltynot racial inequity. J ust as black neighborhoods would be made no better off by the withdrawal of police from white neighborhoods, black victims and potential victims would be made no better off by our refusal to execute murderers, notwithstanding that we are more likely to execute murderers of whites.

Indeed, there is little reason to believe that a system that cannot equitably execute those who murder blacks will somehow impose equitable noncapital punishments. What people pushing abolition of the death penalty must be hoping for is that abolition will reduce the level of punishment meted out to (mostly white) murderers of whites, while leaving intact (save for the elimination of a rare execution) the level of punishment meted out to murderers of blacks. M ore likely, what we would have is a general ratcheting down of punishments, with the inequities remaining.

Scholars who study the death penalty often also study several other decisions in the process that might theoretically lead to execution. What they almost invariably find is large-scale bias in these earlier decisions, including decisions that would continue to be made if the death penalty were abolished. O ne particularly interesting study (although pre-Furman) was conducted by Franklin Zimring, J oel Eigen, and Sheila O 'M alley, and examined the records of 245 persons arrested for homicide in Philadelphia in $1970 .^{60}$ Of the 245,170 were eventually convicted of some charge. ${ }^{61}$ Sixty-five percent of the defendants who killed a white person received either life imprisonment or a death sentence,

59. It is not the case that all or even a majority of studies show a deterrent effect of executions. But several studies, including some of the most sophisticated ones, do. See, e.g., Dale O. Cloninger, Capital Punishment and Deterrence: A Portfolio A pproach, 24 J. A PPLIED E CON. 635 (1992); I saac E hrlich, Capital Punishment and D eterrence: Some Further Thoughts and A dditional Evidence, $85 \mathrm{~J}$. POL. E CON. 741 (1977); I saac E hrlich, The D eterrent E ffect of Capital Punishment: A Question of L ife and D eath, 65 A M. E CON. R E V. 397 (1975); Stephen K. L ayson, H omicide and D eterrence: A R eexamination of the U nited States Time-Series E vidence, 52 S. E CON. J . 68 (1985); D avid L ester, Executions as a Deterrent to H omicides, 44 PSY CH. REP. 562 (1979); D avid L ester, D eterring E ffect of Executions on a M urder as a Function of N umber and Proportion of Executions, 45 PSY CH. REP. 598 (1979); R adelet, supra note 26; K enneth I. Wolpin, Capital Punishment and Homicide in England: A Summary of Results, 68 A M. E CON. REV. 422 (1978); J ames A. Y unker, Testing the D eterrent E ffect of Capital Punishment, 19 CRIM IN OLOGY 626 (1982).

60. See Franklin E. Zimring et al., P unishing $\mathrm{H}$ omicide in Philadelphia: Perspectives on the $\mathrm{D}$ eath Penalty, 43 U. CHI. L. REV. 227, 229 (1976).

61. Seeid. at 229 . 
while only twenty-five percent of those who killed a black person did. ${ }^{62}$ Since these murders produced only three death sentences (all imposed on blacks who killed whites), ${ }^{63}$ most of the apparent racial unfairness involved life imprisonment. A Ifred Blumstein, in a study of the racial disproportionality of prison populations, found that in 1991, blacks were underrepresented among prisoners convicted of murder. ${ }^{64}$ There were many limitations to Blumstein's study, including failure to control for aggravating circumstances, and a research design that leaves possible racial discrimination in arrests entirely out of account. But his results strongly imply that the system does for imprisonment what it does with regard to executions: underpunish those who kill blacks.

W illiam J. B owers, as we have already discussed, found that defendants who killed whites were more likely to be indicted for first-degree murder, rather than a lesser charge, and more likely to be convicted of first-degree murder than defendants who killed blacks. ${ }^{65} \mathrm{~A}$ long similar lines, $\mathrm{M}$ ichael R adelet, in a study of indictments for murder in Florida, found that eighty-five percent of the killers of white victims were indicted for first-degree murder, while only 53.6 percent of the killers of black victims were. ${ }^{66}$

L eigh Bienen and her colleagues, in their study of $\mathrm{New}$ Jersey homicides discussed above, ${ }^{67}$ examined the issue of whether a particular case was plea bargained or went to trial. Cases involving white victims were found to have gone to trial more often than cases involving either black or $\mathrm{H}$ ispanic victims. ${ }^{68}$

O ne particularly interesting study involved prosecutors' decisions to upgrade or downgrade a homicide charge. ${ }^{69}$ A n upgrade involved a prosecutor charging a felony connected with the homicide when no such felony was mentioned in the police report. A downgrade involved a prosecutor not charging a felony even though the police report indicated its commission. A statistical model that controlled for the circumstances of the crime and of the offender showed that murders involving white victims were more likely to be upgraded than murders involving black victims. ${ }^{70}$

A II of this makes perfect sense. If the system is biased toward punishing those who murder whites, it is implausible indeed that decisions leading up to sentencing are made with strict racial fairness, and only the imposition of a death sentence is racially biased. If people want to punish those who murder whites more harshly than those who murder blacks, this is likely to be reflected in prosecutors' decisions to move ahead with a case, in decisions about whether

62. See id. at 232.

63. Seeid. at 233 .

64. See A Ifred Blumstein, Racial Disproportionality of U.S. Prison Populations Revisited, $64 \mathrm{U}$.

COLO. L. REV. 743, 751 (1993). Note that Blumstein's 1979 data did not show this disproportionality.

65. See B owers, supra note 24, at 1073, 1084.

66. See R adelet, supra note 26 , at 922 .

67. See B ienen et al., supra note 34 .

68. See id. at 226.

69. See Michael L. Radelet $\&$ Glenn L. Pierce, Race and Prosecutorial D iscretion in Homicide Cases, 19 L . \& So C'Y R EV . 587, 599-605 (1985).

70. Seeid. at 608. 
to plea-bargain, in the allocation of staff to a particular case, in the decision to indict on more or less serious charges, and in jury verdicts. E ven in sentencing, abolition of the death penalty does not eliminate racial unfairness; it only narrows the range of possible punishments. While not all decision points have been studied equally well, theoretically the pervasive undervaluing of the lives of black victims would be expected to be reflected at every point that involves the exercise of discretion.

Interestingly, a very large literature testifies to the racial unfairness of the criminal justice system below the level of capital crimes and capital punishment, although a lot of this literature supports the "mass market" version of the disparity argument. For example, J oseph $\mathrm{G}$ astwirth and Tapan Nayak have presented strong evidence that drug offenders who are black are more likely to be sentenced to life imprisonment than similar white offenders. ${ }^{71}$ O ne interpretation of this, however, is that the system is in fact being responsive to the black community, which feels threatened by drugs in a way that few if any white localities do. The evidence, however, is mixed. Blumstein, in the study discussed above, compares the prison population to the population of arrestees, on the assumption that any disproportion will reflect treatment within the criminal justice system. He finds blacks and whites treated equally in robbery cases, blacks treated more leniently in murder cases (as we have already seen), and blacks treated more harshly in other kinds of cases, especially in drug cases. ${ }^{72}$ The disproportionate treatment of blacks in some kinds of cases might be racial discrimination or instead might be the result of legitimate factors not controlled for. ${ }^{73}$

The relevance of studies dealing with offenses below the level of murder is questionable, however. Eliminating the death penalty does not really make murder just like robbery, assault, or drug dealing. So the best evidence comes from studies explicitly dealing with how murderers are treated. Studies of racial unfairness with regard to lesser crimes only serve to make us cautious about assuming that the system is unfair only with regard to executions.

Thus, we have a criminal justice system that punishes those who murder whites more severely that those who murder blacks. A bolishing the death penalty would eliminate the most visible outcropping of injustice, and perhaps make us feel better, but it would not aid the law-abiding blacks who are the chief victims of the system. M ost importantly, it would not address, in any substantial way, the total structure of unfairness.

71. See J oseph L. G astwirth \& Tapan Nayak, Statistical A spects of Cases Concerning Racial Discrimination in Drug Sentencing: Stephens V. State and U.S. V. A rmstrong, 87 J. CRIM. L. \& CRIMINOLOGY 583 (1997).

72. See B lumstein, supra note 64 , at $747,751$.

73. Seeid. at 746 . 